E-ISSN 2549-8703 I P-ISSN 2302-7282

\title{
PENGARUH PEMBERIAN KOMPOSIT KITOSAN ASAP CAIR TERHADAP PERTUMBUHAN CABAI RAWIT MERAH Capsicum frutescens Linn.
}

\section{THE EFFECT OF LIQUID SMOKE AND CHITOSAN COMPOSITION ON THE GROWTH OF RED CAYENNE PEPPER Capsicum frutescens Linn.}

\author{
Sasi Gendro Sari ${ }^{1)^{*}}$, Evie Selvia ${ }^{1)}$, Chatimatun Nisa ${ }^{2)}$, Ahmad Budi Junaidi ${ }^{3)}$
}

Diterima: 18 September 2019

Disetujui: 4 Mei 2020

\begin{abstract}
Afiliasi Penulis:
1) Program Studi Biologi FMIPA Universitas Lambung Mangkurat, Jl. A. Yani km. 35,8 Banjarbaru Kalimantan Selatan

2) Program Studi Agronomi

Fakultas Pertanian Universitas Lambung Mangkurat, Jl. A. Yani km. 35 Banjarbaru - Kalimantan Selatan

3) Program Studi Kimia FMIPA Universitas Lambung Mangkurat, Jl. A. Yani km. 35,8 Banjarbaru Kalimantan Selatan
\end{abstract}

\begin{tabular}{l}
\hline Alamat Korespondensi: \\
*sgsari@ulm.ac.id \\
\hline \\
\hline Cara Sitasi: \\
Sari, S.G., E. Selvia, C. Nisa, \& \\
A.B. Junaidi. 2020. Pengaruh \\
pemberian komposit kitosan asap \\
cair terhadap pertumbuhan cabai \\
rawit merah Capsicum frutescens \\
Linn. Biotropika: Journal of \\
Tropical Biology 8 (1): 8-12. \\
\hline
\end{tabular}

\section{PENDAHULUAN}

Cabai rawit merah (Capsicum frutescens) merupakan salah satu komoditas sayuran penting bernilai ekonomis tinggi. Cabai ini

\section{ABSTRAK}

Pemanfaatan kitosan asap cair dalam meningkatkan pertumbuhan cabai rawit merah Capsicum frutescens penting dipelajari karena kebutuhan cabai rawit merah meningkat setiap tahunnya namun tidak disertai dengan peningkatan produktifitas yang seimbang. Penelitian ini bertujuan untuk mengetahui dosis kitosan asap cair yang paling optimal dalam mendukung pertumbuhan cabai rawit merah. Rancangan Acak Lengkap (RAL) faktorial menggunakan empat ulangan dengan pemberian dosis kitosan asap cair sebesar 5, 7,5, 10, 12,5 dan $15 \%$ digunakan dalam penelitian. Parameter yang diamati adalah rasio $\mathrm{C} / \mathrm{N}$ tanah, tinggi tanaman, jumlah daun, berat kering tanaman. Sebelum ditanam selama delapan minggu, biji cabai direndam dalam larutan akuades dan kitosan asap cair. Hasil menunjukkan bahwa penggunaan dosis kitosan asap cair sebesar $7,5 \%$ dan $10 \%$ menunjukkan pertumbuhan yang paling optimal berdasarkan tinggi tanaman, jumlah daun, berat kering tanaman dibandingkan dosis lainnya.

Kata Kunci: aplikasi, asap cair, cabai rawit, dosis, kitosan

\begin{abstract}
The application of liquid smoke and chitosan on the growth of red cayenne pepper Capsicum frutescens played crucial roles to increase its productivity due to high demands of this pepper. The research determined the optimal dose of liquid smoke and chitosan composition on the growth of red cayenne pepper. Completely Randomized Design Factorial using four replications was used with five different concentrations of liquid smoke and chitosan composition such as $5 \%, 7,5 \%, 10 \%, 12,5 \%$ and $15 \%$. Parameter of plant growth was measured, namely height of plants, amount of leaves, dry weight of plants, and the ratio of carbon and nitrogen soil. The seeds were soaked in aquades and liquid smoke and chitosan composition before planted for 8 weeks. The results showed that the optimal dose of liquid smoke and chitosan composition were 7,5\% and $10 \%$ based on the height, the number of leaves, dry weight of plants compared to other doses.
\end{abstract}

Keywords: application, chitosan, cayenne pepper, dose, liquid smoke

sangat diminati dalam keadaan segar sehingga ketersediaan di pasar sangat besar [1]. Setiap tahun, permintaan cabai meningkat sejalan dengan pertambahan jumlah penduduk dan industri makanan [2]. Akan tetapi, ketersediaan cabai rawit menurun karena kehadiran hama cabai seperti Thrips (Thrips parvispinus Karny.), lalat buah (Bactrocera sp.), tungau (Polyphagotarsonemus latus dan Tetranychus 
sp.), kutu daun (Aphididae) dan serangan penyakit seperti layu bakteri ralstonia (Ralstonia solanacearum) dan disebabkan oleh virus seperti penyakit virus kuning (Gemini virus) [3]. Upaya untuk mengurangi serangan hama adalah dengan pengendalian hama menggunakan pestisida alami.

Pestisida alami yang dapat dimanfaatkan yaitu aplikasi pemanfaatan kitosan dan asap cair. Kitosan merupakan turunan dari kitin yang diperoleh dari limbah kulit udang dan memiliki sifat antimikroba [4,5]. Kitosan dapat menjadi sumber karbon dan mempercepat proses fiksasi nitrogen bagi tanaman [6]. Kitosan mampu meningkatkan pertumbuhan tanaman dan akar, mempercepat waktu berbunga, berat dan hasil buah [7]. Selain itu, menurut [8] kitosan mampu meningkatkan induksi antibodi tanaman, menginduksi fitoaleksin dan protein inhibitor yang terkandung dalam lignin. Kitosan mampu meningkatkan sinyal untuk sintesis hormon giberelin dan auksin [9]. Oleh karena itu, pemanfaatan kitosan pada penelitian ini diharapkan dapat menjadi bioimunizer tanaman cabai terhadap serangan hama atau penyakit lainnya dan dapat merangsang hormon pertumbuhan tanaman cabai rawit merah.

Aplikasi kitosan memiliki kendala dalam sifat kelarutannya yaitu tidak larut dalam air, sedikit larut dalam asam kuat seperti $\mathrm{HCl}$, HNO3, dan H3PO4. Akan tetapi, kitosan mudah larut dalam asam-asam lemah encer seperti asap cair, sehingga dalam penelitian ini kitosan dilarutkan terlebih dahulu dalam larutan asap cair. Asap cair yang digunakan berasal dari kondensasi uap pembakaran langsung dan tidak langsung dari kayu, bongkol kelapa sawit dan ampas hasil penggergajian kayu [10].

Oleh karena itu, pengaruh komposit kitosan asap cair dari bahan limbah pembuatan arang diharapkan dapat meningkatkan pertumbuhan tanaman cabai rawit merah. Bahan baku asap cair yang digunakan berasal dari pembakaran kayu dalam proses pembuatan arang di Kalimantan Selatan. Tujuan penelitian ini adalah untuk mengetahui dosis optimal pemberian kitosan asap cair terhadap pertumbuhan tanaman cabai rawit merah budidaya yang didasarkan kepada pengukuran parameter pertumbuhan tanaman. Manfaat penelitian adalah sebagai informasi teknis bagi pembudidaya cabai terkait aplikasi kitosan dan asap cair dari limbah arang yang mampu dijadikan sebagai pestisida alami yang ramah lingkungan.

\section{METODE PENELITIAN}

Waktu dan Tempat Penelitian. Penelitian ini dilakukan selama tiga bulan dari bulan Maret sampai Mei 2018 di greenhouse Lab. Biologi FMIPA Universitas Lambung Mangkurat.

Persiapan Kitosan dan Asap Cair. Pengenceran asap cair dilakukan menggunakan akuades dan ditambahkan kitosan $80 \mathrm{ppm}$. Tingkat keasaman komposit kitosan asap cair perlu dinetralkan terlebih dahulu dengan menambahkan sedikit demi sedikit larutan kalsium oksida sampai $\mathrm{pH}$ bernilai 6-7. Kemudian variasi dosis kitosan asap cair dibuat dengan lima variasi konsentrasi yaitu:

- Konsentrasi 5\% (kitosan 80 ppm + asap cair $50 \mathrm{~mL}+$ akuades $1 \mathrm{~L}+\mathrm{CaO} 0,75 \mathrm{~g} / \mathrm{L}$ )

- Konsentrasi 7,5\% (kitosan 80 ppm + asap cair $75 \mathrm{~mL}+$ akuades $1 \mathrm{~L}+\mathrm{CaO} 1,5 \mathrm{~g} / \mathrm{L})$

- Konsentrasi 10\% (kitosan 80 ppm + asap cair $100 \mathrm{~mL}+$ akuades $1 \mathrm{~L}+\mathrm{CaO} 2,0 \mathrm{~g} / \mathrm{L}$ )

- Konsentrasi 12,5\% (kitosan 80 ppm + asap cair $125 \mathrm{~mL}+$ akuades $1 \mathrm{~L}+\mathrm{CaO} 2,5 \mathrm{~g} / \mathrm{L}$ )

- Konsentrasi 15\% (kitosan 80 ppm + asap cair $150 \mathrm{~mL}+$ akuades $1 \mathrm{~L}+\mathrm{CaO} 3,5 \mathrm{~g} / \mathrm{L}$ )

Penyemaian Biji Cabai. Sebanyak 168 biji cabai dipilih yang terbaik kemudian sebanyak 84 biji direndam dalam akuades dan sisanya direndam dalam kelima variasi konsentrasi kitosan asap cair selama 4 jam. Biji kemudian disemai dalam media semai dengan komposisi tanah halus dan pupuk kandang sebanyak $1: 1$ sampai 30 hari dan muncul 6-8 helai daun untuk kemudian dipindahkan ke dalam pot pemeliharaan.

Jenis perlakuan yang digunakan. Perlakuan yang diberikan terhadap tanaman cabai adalah:

- ATP = Biji direndam aquades, tanah tanpa pupuk

- $\mathrm{ADP}=$ Biji direndam aquades, tanah diberi pupuk

- $\mathrm{AK} 5 \%=\mathrm{Biji}$ direndam aquades, tanah dipupuk, tanaman disemprot kitosan dan asap cair konsentrasi 5\%

- $\mathrm{AK} 7,5 \%=$ Biji direndam aquades, tanah dipupuk, tanaman disemprot kitosan dan asap cair konsentrasi 7,5\% 
- $\mathrm{AK} 10 \%=\mathrm{Biji}$ direndam aquades, tanah dipupuk, tanaman disemprot kitosan dan asap cair konsentrasi $10 \%$

- AK12,5\%= Biji direndam aquades, tanah dipupuk, tanaman disemprot kitosan dan asap cair konsentrasi $12,5 \%$

- $\mathrm{AK} 15 \%=$ Biji direndam aquades, tanah dipupuk, tanaman disemprot kitosan dan asap cair konsentrasi $15 \%$

- KTP = Biji direndam kitosan asap cair, tanah tanpa pupuk

- KDP = Biji direndam kitosan asap cair, tanah diberi pupuk

- $\mathrm{KK} 5 \%=$ Biji direndam serta tanaman disemprot kitosan dan asap cair konsentrasi $5 \%$

- $\mathrm{KK} 7,5 \%=$ Biji direndam serta tanaman disemprot kitosan dan asap cair konsentrasi $7,5 \%$

- $\mathrm{KK} 10 \%=$ Biji direndam serta tanaman disemprot kitosan dan asap cair konsentrasi $10 \%$

- $\mathrm{KK} 12,5 \%=$ Biji direndam serta tanaman disemprot kitosan dan asap cair konsentrasi $12,5 \%$

- $\mathrm{KK} 15 \%=$ Biji direndam serta tanaman disemprot kitosan dan asap cair konsentrasi $15 \%$

Penanaman dan Pemeliharaan Cabai. Sebanyak 56 polybag disiapkan dengan berat masing-masing polybag $5 \mathrm{~kg}$ yang berisi campuran tanah dari lahan kebun warga di Banjarbaru dan pupuk organik kotoran sapi merk Horti Center dengan perbandingan $2: 1$. Tanah dari setiap polybag diambil sebanyak 10 $\mathrm{g}$ untuk diukur rasio $\mathrm{C} / \mathrm{N}$ dan selanjutnya media tanam didiamkan di tempat terlindung dari cahaya matahari langsung dan hujan selama 7 hari untuk kemudian bibit cabai siap ditanam. Pemupukan dengan penambahan pupuk NPK dilakukan sebanyak $5 \mathrm{~g}$ setiap polybag pada hari ke-15, ke-30 dan ke-50 setelah tanam di pagi hari. Penyiraman dilakukan setiap hari dengan jumlah air sebanyak $1 \mathrm{~L}$ setiap polybag. Pengendalian gulma dilakukan seminggu sekali dengan cara dicabut secara langsung.

Parameter Pertumbuhan Cabai. Rasio $\mathrm{C} / \mathrm{N}$ tanah diukur sebelum penanaman dan sesudah pemanenan dengan cara komposit, yaitu dengan mencampurkan tanah menjadi satu dari masing-masing perlakuan (empat ulangan). Sebelum penanaman, tanah yang diambil dari lahan warga dan sudah dimasukkan ke dalam polybag diambil $10 \mathrm{~g}$ untuk diukur rasio $\mathrm{C} / \mathrm{N}$ tanah sebelum diberi tambahan pupuk kandang. Setelah pemanenan, tanah dalam pot diambil $10 \mathrm{~g}$ untuk diukur rasio $\mathrm{C} / \mathrm{N}$ tanah. Tinggi tanaman diukur dan jumlah daun dihitung setiap dua minggu sekali selama 56 hari tanam ( 8 minggu). Berat kering tanaman ditimbang setelah pemanenan.

Rancangan Penelitian dan Analisis Data. Penelitian ini menggunakan Rancangan Acak Lengkap (RAL) factorial dengan empat ulangan sehingga didapatkan sebanyak 56 sampel percobaan. Data kuantitatif pada parameter pertumbuhan cabai diuji menggunakan analisis ragam (Anova) untuk kemudian dilakukan uji Duncan pada taraf nyata $5 \%$.

\section{HASIL DAN PEMBAHASAN}

Rasio C/N Tanah. Tabel 1 di bawah ini adalah rasio $\mathrm{C} / \mathrm{N}$ tanah sebelum dan sesudah dilakukan pemanenan cabai setelah delapan minggu tanam.

Tabel 1. Rasio C/N tanah

\begin{tabular}{lcc}
\hline Perlakuan & \multicolumn{2}{c}{ Rasio C/N tanah } \\
\cline { 2 - 3 } & Sebelum & Sesudah \\
\hline ATP & 4,10 & 8,85 \\
ADP & 4,21 & 6,00 \\
AK5\% & 4,21 & 4,97 \\
AK7,5\% & 4,21 & 3,34 \\
AK10\% & 4,21 & 14,49 \\
AK12,5\% & 4,21 & 2,79 \\
AK15\% & 4,21 & 10,48 \\
KTP & 9,50 & 4,69 \\
KDP & 8,47 & 5,40 \\
KK5\% & 8,47 & 12,03 \\
KK7,5\% & 8,47 & 8,85 \\
KK10\% & 8,47 & 8,32 \\
KK12,5\% & 8,47 & 4,95 \\
KK15\% & 8,47 & 5,40 \\
\hline
\end{tabular}

Rasio C/N tanah dikatakan optimal dalam mencukupi kebutuhan unsur hara tanaman apabila menurut [11] rasio $\mathrm{C} / \mathrm{N}$ tanah berkisar antara 10-12. Oleh karena itu, perlakuan AK15\% (Biji direndam akuades dan disemprot kitosan asap cair 15\%) dan KK5\% (biji direndam dan disemprot kitosan asap cair 5\%) menunjukkan rasio $\mathrm{C} / \mathrm{N}$ tanah yang optimal, dimana bahan organik yang terkandung dalam tanah dapat diserap secara optimal oleh tanaman cabai. Hal tersebut disebabkan karena rasio $\mathrm{C} / \mathrm{N}$ bahan organik mendekati atau sama dengan rasio $\mathrm{C} / \mathrm{N}$ tanah. Selain itu, pemberian kitosan asap cair mampu meningkatkan 
kandungan karbon tanah dan proses fiksasi nitrogen oleh bakteri [6] serta mampu menginduksi sintesis hormon pertumbuhan tanaman seperti auksin dan giberelin [9].

Pertumbuhan Cabai. Parameter pertumbuhan cabai seperti tinggi tanaman dan jumlah daun selama delapan minggu masa tanam dapat dilihat pada Tabel 2.

Tabel 2. Pengaruh penyemprotan kitosan asap cair terhadap tinggi dan jumlah daun cabai

\begin{tabular}{lcc}
\hline Perlakuan & $\begin{array}{c}\text { Tinggi } \\
\text { tanaman }(\mathrm{cm})\end{array}$ & $\begin{array}{c}\text { Jumlah daun } \\
\text { (helai) }\end{array}$ \\
\hline ATP & $20,13 \mathrm{a}$ & $14 \mathrm{a}$ \\
ADP & $21,63 \mathrm{bc}$ & $14 \mathrm{bc}$ \\
AK5\% & $22,63 \mathrm{c}$ & $15 \mathrm{bcd}$ \\
AK7,5\% & $24,13 \mathrm{f}$ & $16 \mathrm{e}$ \\
AK10\% & $23,38 \mathrm{de}$ & $15 \mathrm{de}$ \\
AK12,5\% & $22,25 \mathrm{bc}$ & $14 \mathrm{bc}$ \\
AK15\% & $21,50 \mathrm{~b}$ & $14 \mathrm{~b}$ \\
KTP & $20,50 \mathrm{a}$ & $14 \mathrm{a}$ \\
KDP & $22,50 \mathrm{bc}$ & $14 \mathrm{bc}$ \\
KK5\% & $23,63 \mathrm{~d}$ & $15 \mathrm{~cd}$ \\
KK7,5\% & $24,38 \mathrm{ef}$ & $16 \mathrm{e}$ \\
KK10\% & $24,25 \mathrm{ef}$ & $15 \mathrm{e}$ \\
KK12,5\% & $22,50 \mathrm{c}$ & $15 \mathrm{bc}$ \\
KK15\% & $21,75 \mathrm{bc}$ & $14 \mathrm{bc}$ \\
Uji D & $*$ & $*$ \\
\hline Ket: $\quad$ berpengaruh nyata pada taraf $5 \%$
\end{tabular}

Pertumbuhan vegetatif tanaman cabai rawit dengan perlakuan penyemprotan kitosan asap cair lebih baik bila dibandingkan dengan kontrol (tanpa dan penambahan pupuk kandang dan NPK). Hal ini mengindikasikan bahwa penyemprotan kitosan 80 ppm dengan variasi konsentrasi asap cair memberikan hasil yang berbeda nyata setelah diuji melalui analisis ragam dan dilanjutkan dengan uji Duncan. Selain itu, tanaman yang direndam dan disemprot kitosan asap cair konsentrasi $7,5 \%$ dan $10 \%$ memiliki kecepatan tumbuh yang lebih baik dari segi tinggi tanaman dan jumlah daun bila dibandingkan dengan perlakuan lain.

Berat kering tanaman dapat dilihat pada Tabel 3. Rasio berat tajuk dan akar untuk perlakuan perendaman biji baik dalam larutan akuades dan kitosan asap cair serta penyemprotan dengan kitosan asap cair dengan konsentrasi 7,5\% dan 10\% (AK7,5\%, AK10\%, KK $7,5 \%$ dan KK10\%) menunjukkan pertumbuhan tajuk yang lebih baik bila dibandingkan perlakuan lainnya.
Tabel 3. Rasio berat kering tajuk dan akar tanaman cabai rawit merah

\begin{tabular}{llc}
\hline No & Perlakuan & Rasio tajuk : akar* \\
\hline 1 & ATP & $1,14: 1 \mathrm{a}$ \\
2 & ADP & $1,15: 1 \mathrm{ab}$ \\
3 & AK5\% & $1,18: 1 \mathrm{~cd}$ \\
4 & AK7,5\% & $1,25: 1 \mathrm{e}$ \\
5 & AK10\% & $1,3: 1 \mathrm{e}$ \\
6 & AK12,5\% & $1,17: 1 \mathrm{~cd}$ \\
7 & AK15\% & $1,19: 1 \mathrm{bc}$ \\
8 & KTP & $1,24: 1 \mathrm{~cd}$ \\
9 & KDP & $1,31: 1 \mathrm{~d}$ \\
10 & KK5\% & $1,33: 1 \mathrm{~d}$ \\
11 & KK7,5\% & $1,4: 1 \mathrm{e}$ \\
12 & KK10\% & $1,42: 1 \mathrm{e}$ \\
13 & KK12,5\% & $1,22: 1 \mathrm{~d}$ \\
14 & KK15\% & $1,26: 1 \mathrm{~cd}$ \\
\hline *) huruf yang berbeda antar kolom yang sama \\
\multicolumn{3}{c}{ menunjukkan perbedaan yang nyata antar } \\
perlakuan
\end{tabular}

Hal ini menunjukkan bahwa penyemprotan kitosan asap cair dengan konsentrasi 7,5\% dan $10 \%$ mampu meningkatkan derajat tumbuh dan kecepatan tumbuh tanaman. Menurut [9] menyatakan bahwa kitosan dapat meningkatkan sinyal untuk sintesis hormon giberelin serta dapat meningkatkan biosintesis auksin dalam mendukung pertumbuhan dan perkembangan tanaman. Asap cair yang berperan dalam melarutkan kitosan menurut [12] mampu mempercepat pertumbuhan tajuk dan akar tanaman serta mampu meningkatkan bioimunitas tanaman.

\section{KESIMPULAN}

Aplikasi pemanfaatan kitosan yang dilarutkan dalam asap cair yang berasal dari limbah arang dengan konsentrasi 7,5\% dan $10 \%$ memberikan pengaruh yang paling optimal dalam pertumbuhan dan perkembangan tanaman cabai rawit merah. Perlu dilakukan penelitian lanjutan untuk mengetahui ketahanan tanaman cabai terhadap penyakit pada perlakuan perendaman dan penyemprotan kitosan asap cair dengan konsentrasi $7,5 \%$ dan $10 \%$.

\section{UCAPAN TERIMA KASIH}

Kementerian Riset dan Teknologi atas pemberian hibah Penelitian Dasar Unggulan Perguruan Tinggi Tahun Anggaran 2018/2019. 


\section{DAFTAR PUSTAKA}

[1] Umam K (2017) Respon kualitas cabai rawit merah Capsicum frutescens $\mathrm{L}$. terhadap suhu penyimpanan. Departemen Taknik Mesin dan Biosistem Fakultas Teknologi Pertanian, IPB, Bogor.

[2] Subagyono (2010) Budidaya dan pascapanen cabai merah Capsicum annuum L. Balai Pengkajian Teknologi Pertanian, Jawa Tengah.

[3] Balai Pengkajian Teknologi Pertanian BPTP Jambi (2004) Hama dan penyakit pada tanaman cabai serta pengendaliannya. Balai Besar Pengkajian dan Pengembangan Teknologi Pertanian Badan Penelitian dan Pengembangan Pertanian, Kementerian Pertanian, Jambi.

[4] Terbojevich M, Muzzarelli RAA (2000) Chitosan. University of Ancona.

[5] Suptijah P (2006) Deskripsi karakteristik fungsional dan aplikasi kitin dan kitosan. Prosiding Seminar Nasional Kitin dan Kitosan. Departemen Teknologi Hasil Pertanian, IPB, Bogor, pp. 14-24.

[6] Boonlertnirun S, Boonraung C, Suvanasara R (2008) Application of chitosan in rice production. Journal of Metal, Materials, and Mineral 18(2): 4752.

[7] Ohta M, Suda K, Hosoki T (2004) Effects of chitosan soil mixture treatment in the seedling stage on the growth and flowering of several ornament plants. Journal Hort Scie 73: 66-68.

[8] Chandrkrachang S, Sompongchaiyakul P, Sangtain S (2005) Profitable spin-off from using chitosan in orchid farming in Thailand. Journal of Metal, Materials, and Mineral 15: 45-48.

[9] Uthairatanakij A, Silva JAT, Obsuwan K (2007) Chitosan for improving orchid production and quality. Journal Orchid Science and Biotechnology 1: 1-5.

[10] Pari G (2008) Proses produksi dan pemanfaatan arang, briket arang dan cuka kayu. Pusat Penelitian dan Pengembangan Hasil Hutan Bogor, Bogor.

[11] Murbandono, HIS (1992) Membuat kompos. Penebar Swadaya, Jakarta.

[12] Basri AB (2010) Manfaat asap cair untuk tanaman. Balai Pengkajian Teknologi Pertanian Aceh, Aceh. 